\title{
Structural properties of Mn-substituted hercynite
}

\author{
Ilona Jastrzębska, \\ Wiktor Bodnar, \\ Kerstin Witte, \\ Eberhard Burkel, \\ Pawel Stoch, \\ Jacek Szczerba
}

\begin{abstract}
In this work spinel series with the general formula $\mathrm{Fe}_{1-x} \mathrm{Mn}_{x} \mathrm{Al}_{2} \mathrm{O}_{4}$ (where $x=0,0.3,0.5$ and 0.7 ) were synthesized and characterized with respect to their structure and microstructure. X-ray diffractometry (XRD) was used to identify the phase composition that revealed a single phase spinel material. Rietveld refinements of the XRD patterns were carried out in order to determine the lattice and oxygen positional parameters of the spinel compounds. Mössbauer effect measurements were performed at room temperature to determine the local chemical environment of the Fe ions, their valences, and degrees of spinels inversion. It was shown that an increase in the $\mathrm{Mn}$ content led to a decrease in the ratio of $\mathrm{Fe}^{2+}$ to $\mathrm{Fe}^{3+}$. The results obtained from Mössbauer spectroscopy (MS) were used to establish the chemical formulas of the synthesized spinels. Finally, the microstructure that was observed using scanning electron microscopy (SEM) showed a compact microstructure with an octahedral crystal habit.
\end{abstract}

Keywords: $\mathrm{FeAl}_{2} \mathrm{O}_{4} \bullet \mathrm{MnAl}_{2} \mathrm{O}_{4} \bullet$ hercynite $\bullet$ spinel $\bullet$ galaxite $\bullet$ Mössbauer spectroscopy

I. Jastrzębska ${ }^{凶}$, P. Stoch, J. Szczerba

Department of Ceramics and Refractories,

Faculty of Materials Science and Ceramics,

AGH University of Science and Technology,

30 A. Mickiewicza Ave., 30-059 Kraków, Poland,

E-mail: ijastrz@agh.edu.pl

W. Bodnar, K. Witte, E. Burkel

Physics of New Materials,

Institute of Physics,

Faculty of Mathematics and Natural Sciences,

University of Rostock,

23 Albert-Einstein-Str., 18059 Rostock, Germany

Received: 3 August 2016

Accepted: 28 October 2016

\section{Introduction}

Spinels are compounds that have the general formula $\mathrm{A}^{2+} \mathrm{B}_{2}^{3+} \mathrm{O}_{4}$ where $\mathrm{A}$ and $\mathrm{B}$ are metallic cations. The formal charges of $\mathrm{A}$ and $\mathrm{B}$ are strictly specified and they are a criterion of the spinel type. There are three types of spinel compounds, the so-called 2-3, 4-2 and 6-1 spinels, where the numbers indicate the formal charges of the cations. The first cation of each pair occupies a tetrahedral site $\left(\mathrm{T}_{\mathrm{d}}\right)$, while the second one is located in the octahedral position $\left(\mathrm{O}_{\mathrm{h}}\right)$ [1].

Hercynite $\left(\mathrm{Fe}^{2+} \mathrm{Al}_{2} \mathrm{O}_{4}\right)$ is a 2-3-type spinel with a normal cation distribution, which means that all of the divalent ferrous ions occupy tetrahedral $\left(\mathrm{T}_{\mathrm{d}}\right)$ positions, whereas the $\mathrm{Al}^{3+}$ cations occupy octahedral $\left(\mathrm{O}_{\mathrm{h}}\right)$ sites. Nevertheless, this order in the cation arrangement is impaired at temperatures above absolute zero causing cation exchange in the real spinel-type compounds between $\mathrm{T}_{\mathrm{d}}$ and $\mathrm{O}_{\mathrm{h}}$ sites [1-3]. This disorder is described by the inversion parameter $i$, which stands for the fraction of trivalent ions in the $\mathrm{T}_{\mathrm{d}}$ interstices. The formula of such a mixed spinel can be expressed as $\left(\mathrm{Fe}_{1-x} \mathrm{Al}_{x}\right)\left(\mathrm{Fe}_{x} \mathrm{Al}_{2-x}\right) \mathrm{O}_{4}$. The inversion parameter ranges from 0 (normal spinel) to 1 (inverse spinel). Typical representatives of inverse spinels are magnetite $\left(\mathrm{Fe}_{3} \mathrm{O}_{4}\right)$ [4] and jacobsite $\left(\mathrm{MnFe}_{2} \mathrm{O}_{4}\right)$ [5].

As a typical normal spinel compound, $\mathrm{FeAl}_{2} \mathrm{O}_{4}$ exhibits a cubic structure $F d-3 m$ (space group 227) 
Table 1. Crystal structure parameters for the investigated spinel series

\begin{tabular}{lccc}
\hline Sample & $\begin{array}{c}\text { Theoretical chemical } \\
\text { formula }\end{array}$ & $\begin{array}{c}\text { Lattice parameter, } a \\
{[\AA]}\end{array}$ & $\begin{array}{c}\text { Oxygen positional } \\
\text { parameter, } u[-]\end{array}$ \\
\hline $\mathrm{He} 0$ & $\mathrm{FeAl}_{2} \mathrm{O}_{4}$ & $8.1321(2)$ & $0.254(1)$ \\
$\mathrm{HeMn} 3$ & $\mathrm{Fe}_{0.7} \mathrm{Mn}_{0.3} \mathrm{Al}_{2} \mathrm{O}_{4}$ & $8.1500(2)$ & $0.254(1)$ \\
$\mathrm{HeMn} 5$ & $\mathrm{Fe}_{0.5} \mathrm{Mn}_{0.5} \mathrm{Al}_{2} \mathrm{O}_{4}$ & $8.1813(2)$ & $0.263(1)$ \\
$\mathrm{HeMn} 7$ & $\mathrm{Fe}_{0.3} \mathrm{Mn}_{0.7} \mathrm{Al}_{2} \mathrm{O}_{4}$ & $8.2054(2)$ & $0.264(1)$ \\
\hline
\end{tabular}

symmetry with an $\mathrm{O}$ atom at the $u, u, u$ fractional coordinates and $\mathrm{Fe}$ ions at fixed positions. Fe atoms occupy the $8 a$ Wyckoff's positions $(1 / 8,1 / 8,1 / 8), \mathrm{Al}^{3+}$ ions are located at $16 d$ positions $(1 / 2,1 / 2,1 / 2)$ and $\mathrm{O}^{2-}$ ions are at the $32 e$ positions $(1 / 4,1 / 4,1 / 4)$. The parameter $u$ (the so-called oxygen positional parameter) together with the lattice parameter $a$ change along with the bond distances $\mathrm{T}_{\mathrm{d}}-\mathrm{O}$ and $\mathrm{O}_{\mathrm{h}}-\mathrm{O}$ in order to accommodate the various chemical substitutions in the spinel structure [1].

It is common that spinels exist as solid solutions due to the similar cation radii in the corresponding positions. This phenomenon occurs especially in spinels with identical cation arrangement. For example, hercynite and the spinel sensu stricto $\left(\mathrm{MgAl}_{2} \mathrm{O}_{4}\right)$, as two normal spinels with similar cationic radii $\left(r_{\mathrm{Fe} 2+(\mathrm{IV})}=0.063 \mathrm{~nm}, r_{\mathrm{Mg} 2+(\mathrm{IV})}=0.057 \mathrm{~nm}\right.$ [6] $)$, form a complete solid solution [7]. On the other hand, there is a large miscibility gap between hercynite and magnetite at temperatures below $900^{\circ} \mathrm{C}$ [8-10].

The spinel structure may be maintained when it is occupied by ions with limited ionic radii. Hercynite is a unique spinel that contains the smallest trivalent ion $\left(r_{\mathrm{Al} 3+(\mathrm{VI})}=0.054 \mathrm{~nm}\right.$ [6] $)$ and a ferrous ion, which is one of the largest divalent ions that can create a spinel structure [1]. Divalent manganese $\left(\mathrm{Mn}^{2+}\right)$ is another ion with a radius within the suitable cationic size range appropriate for a spinel structure $\left(r_{\mathrm{Mn} 2+(\mathrm{IV})}\right.$ $=0.066 \mathrm{~nm}$ [6]), and galaxite, $\mathrm{Mn}^{2+} \mathrm{Al}_{2} \mathrm{O}_{4}$, is the corresponding end-member mineral [11].

Hercynite $\left(\mathrm{FeAl}_{2} \mathrm{O}_{4}\right)$-galaxite $\left(\mathrm{MnAl}_{2} \mathrm{O}_{4}\right)$ series are interesting from the point of view of their refractory properties since they are characterized by high melting points $-T_{\mathrm{FeAl} 2 \mathrm{O} 4}=1780^{\circ} \mathrm{C}$ [12] and $T_{\mathrm{MnAl} 2 \mathrm{O} 4}$ $=1835^{\circ} \mathrm{C}$ [13], respectively. Additionally, they have low thermal expansion coefficients that improve the thermal shock resistance of the basic refractories that are applied in cement rotary kilns. It is worth emphasizing that their ability to interdiffuse with a magnesia matrix [14] makes the material more flexible through the local formation of secondary spinels. Therefore, the material is able to withstand thermal as well as mechanical strains that are constantly present in a rotating kiln [15]. The exchange of ions between hercynite and magnesia is of great interest because the transitional spinel solid solutions or hybrid spinels that are created $[15,16]$ contribute to healing the cracks that tend to be generated during operation of the kiln. Hence, those two spinel end-members are called active spinels. Moreover, their potential application as indicators of the oxygen fugacity $\left(f_{\mathrm{O} 2}\right)$ conditions within rocks, geothermometer/geobarometer are also considered in geology $[17,18]$.

Since there has been no systematic study of the hercynite-galaxite series, this work aims to inves- tigate the existence of solid solutions among those synthetically obtained compounds with a special focus on the Fe intracrystalline distributions between $\mathrm{T}_{\mathrm{d}}$ and $\mathrm{O}_{\mathrm{h}}$ sites using Mössbauer spectroscopy (MS).

\section{Materials and methods}

The spinel series with a general formula $\left(\mathrm{Fe}_{1-x} \mathrm{Mn}_{x}\right)$ $\mathrm{Al}_{2} \mathrm{O}_{4}$, where $x$ is equal to 0 (hereafter $\mathrm{He} 0$ ); 0.3 (HeMn3); 0.5 (HeMn5); and 0.7 (HeMn7) were synthesized from analytical grade, crystalline powders of $\alpha \mathrm{Al}_{2} \mathrm{O}_{3}, \alpha \mathrm{Fe}_{2} \mathrm{O}_{3}$ and $\mathrm{MnO}$, which were mixed in stoichiometric proportions (Table 1). Subsequently, the mixtures were pressed into $20 \mathrm{~mm}$ diameter pellets and synthesized by applying arc plasma. The arc plasma synthesis $[19,20]$ was carried out in a SpekoArc 300 arc furnace (Spaw-Projekt, Kraków) that was equipped with a water-cooled copper crucible and a tungsten electrode. The synthesis was conducted in an inert argon gas environment (99.996\% Ar).

The powdered products were tested using X-ray diffraction (XRD). The XRD measurements were performed at room temperature using a PANalytical X'Pert PRO multipurpose diffractometer (MPD) in Bragg-Brentano geometry with $\mathrm{CuK}_{\alpha}$ radiation $(\lambda=1.54056 \AA)$. The patterns were collected over a $2 \theta$ range from $10^{\circ}$ to $90^{\circ}$. The qualitative analyses were performed using X'Pert HighScore Plus software [21]. The structural parameters including lattice parameters $(a)$ and oxygen positional parameters $(u)$ were determined from the Rietveld refinements using MAUD software [22]. The refinements were based on the collected XRD data while taking into account information related to the intersite distribution of $\mathrm{Fe}$ atoms in spinels collected from the analysis of MS results.

The ${ }^{57} \mathrm{Fe}$ Mössbauer spectroscopy studies were performed in transmission geometry at room temperature. The Mössbauer source was $50 \mathrm{mCi}^{57} \mathrm{Co}(\mathrm{Rh})$ and mounted in a FAST ComTec Mössbauer drive unit working in a constant acceleration mode. Mössbauer transmission spectra with 512 channels before folding were collected using a scintillation counter in the velocity range of $\pm 4 \mathrm{~mm} / \mathrm{s}$. The spectrometer was calibrated using a standard $\alpha$-Fe foil at room temperature and the isomer shift values were given with respect to this standard. The analysis of the MS spectra was conducted using WMOSS software [23].

Finally, the fracture surfaces of the investigated materials were observed under the ultra-high resolution scanning electron microscope (SEM) Nova NanoSEM 200, equipped with energy dispersive spectrometer (EDS). 


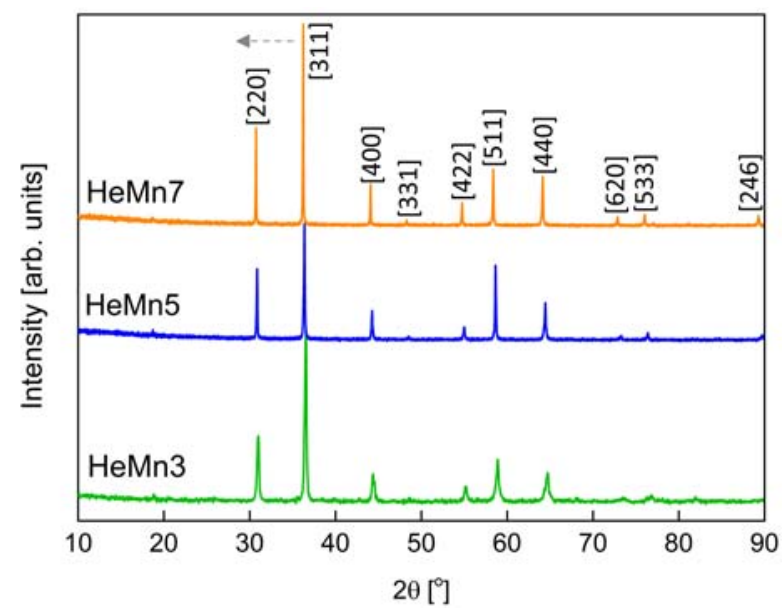

Fig. 1. XRD patterns for the spinel series $\mathrm{Fe}_{1-x} \mathrm{Mn}_{x} \mathrm{Al}_{2} \mathrm{O}_{4}$, where $x=0.3$ (HeMn3), $x=0.5$ (HeMn5) and $x=0.7$ (HeMn7). An arrow indicates the direction of the reflexes shift with the increase of Mn content in a spinel sample.

\section{Results and discussion}

\section{X-ray diffractometry}

The XRD patterns for the synthesized series of spinel materials (HeMn3, HeMn5 and HeMn7) with the corresponding Miller indices are presented in Fig. 1. All of the registered reflexes could be ascribed to the spinel phases of cubic symmetry with the space group $F d-3 m$ (space group number 227). This shows the effectiveness of the arc plasma synthesis in obtaining single phase spinel compounds [19]. The Rietveld refinements were performed based on the structural model (ICSD database) for hercynite [24] supplemented by the information gained from the MS for manganese-substituted hercynite samples. The obtained crystal structure parameters of the solid solutions are summarized in Table 1 . The XRD pattern of $\mathrm{He} 0$ can be found in a previous work [20].
The structure parameters that were determined show a steady increase of the edge of the spinel cell with an increase in the content of manganese ions. However, this is not surprising since the smaller ferrous ions $\left(r_{\mathrm{Fe} 2+}=0.063 \mathrm{~nm}\right.$, [6] $)$ were substituted by the larger manganese ones $\left(r_{\mathrm{Mn} 2+}=0.066 \mathrm{~nm},[6]\right)$. This tendency correlated with the increase of the oxygen positional parameter $u$ as Mn content rose. This suggests that $\mathrm{Mn}$ ions have a strong preference for tetrahedral coordination since a larger value of $u$ indicates an increase in the tetrahedral volume [1]. The tendency of Mn ions to occupy tetrahedron positions in a spinel structure was also observed by Bromiley et al. [18] and Lucchesi et al. [25] and was proven by the electrostatic lattice energy calculation of O'Neill and Navrotsky [26].

\section{Mössbauer spectroscopy}

The Mössbauer patterns measured for both pure hercynite $(\mathrm{He} 0)$ and manganese-substituted hercynites (HeMn3, HeMn5 and HeMn7) are presented in Fig. 2. All of the experimental spectra were decomposed into four quadrupole split doublets $\left(\mathrm{QD}_{1}\right.$, $\mathrm{QD}_{2}, \mathrm{QD}_{3}$ and $\left.\mathrm{QD}_{4}\right)$ that had different hyperfine parameters (isomer shift (IS) and quadrupole splitting (QS)). The decompositions were performed using Lorentzian line shapes. The obtained hyperfine parameters, together with the relative areas under each individual doublet component and iron position assignments, are presented in Table 2 .

The obtained subspectra were ascribed to ferrous $\mathrm{Fe}^{2+}\left(\mathrm{QD}_{1}, \mathrm{QD}_{2}\right.$, and $\left.\mathrm{QD}_{3}\right)$ and ferric $\mathrm{Fe}^{3+}\left(\mathrm{QD}_{4}\right)$ ions according to the values of IS, all of which were present in the crystal structure of the hercynite spinel series. Similar values of the isomer shifts for divalent iron (IS $\approx 0.95 \mathrm{~mm} / \mathrm{s})$ at tetrahedral sites $\left(T_{d}\right)$ in hercynite were obtained by Dézsi [27]. Ferrous ions $\left(\mathrm{Fe}^{2+}\right)$ that were incorporated in the hercynites

Table 2. The hyperfine parameters for spinel series $\left(\mathrm{Fe}_{1-x} \mathrm{Mn}_{x}\right) \mathrm{Al}_{2} \mathrm{O}_{4}$, where $x=0.3,0.5,0.7$

\begin{tabular}{|c|c|c|c|c|c|c|c|}
\hline Sample & Component & $\begin{array}{c}\mathrm{IS} \\
{[\mathrm{mm} / \mathrm{s}]}\end{array}$ & $\begin{array}{c}\mathrm{QS} \\
{[\mathrm{mm} / \mathrm{s}]}\end{array}$ & $\begin{array}{c}\Gamma \\
{[\mathrm{mm} / \mathrm{s}]}\end{array}$ & $\begin{array}{c}\text { Area } \\
{[\%]}\end{array}$ & $\mathrm{Fe}^{2+} / \mathrm{Fe}^{3+}$ & $\begin{array}{c}\text { Position } \\
\text { assignment }\end{array}$ \\
\hline $\mathrm{He} 0$ & $\begin{array}{l}\mathrm{QD}_{1} \\
\mathrm{QD}_{2} \\
\mathrm{QD}_{3} \\
\mathrm{QD}_{4}\end{array}$ & $\begin{array}{l}0.945(2) \\
0.941(2) \\
0.920(2) \\
0.345(4)\end{array}$ & $\begin{array}{l}2.241(9) \\
1.680(9) \\
1.032(2) \\
0.758(7)\end{array}$ & $\begin{array}{l}0.183(7) \\
0.235(2) \\
0.311(7) \\
0.190(5)\end{array}$ & $\begin{array}{l}17.9(2) \\
32.0(4) \\
39.3(3) \\
10.8(2)\end{array}$ & $8.265 \pm 0.08$ & $\begin{array}{l}\mathrm{Fe}^{2+}\left(\mathrm{T}_{\mathrm{d} 1}\right), \mathrm{H}^{1} \\
\mathrm{Fe}^{2+}\left(\mathrm{T}_{\mathrm{d} 2}\right), \mathrm{H} \\
\mathrm{Fe}^{2+}\left(\mathrm{T}_{\mathrm{d} 3}\right), \mathrm{H} \\
\mathrm{Fe}^{3+}\left(\mathrm{O}_{\mathrm{h}}\right), \mathrm{H}\end{array}$ \\
\hline HeMn3 & $\begin{array}{l}\mathrm{QD}_{1} \\
\mathrm{QD}_{2} \\
\mathrm{QD}_{3} \\
\mathrm{QD}_{4}\end{array}$ & $\begin{array}{l}1.010(7) \\
0.960(4) \\
0.934(7) \\
0.284(4)\end{array}$ & $\begin{array}{l}2.112(17) \\
1.662(25) \\
1.088(46) \\
0.968(7)\end{array}$ & $\begin{array}{l}0.169(14) \\
0.205(31) \\
0.242(22) \\
0.200(3)\end{array}$ & $\begin{array}{l}21.7(3) \\
26.7(7) \\
19.4(3) \\
32.2(8)\end{array}$ & $2.11 \pm 0.03$ & $\begin{array}{l}\mathrm{Fe}^{2+}\left(\mathrm{T}_{\mathrm{d} 1}\right), \mathrm{H} \\
\mathrm{Fe}^{2+}\left(\mathrm{T}_{\mathrm{d} 2}\right), \mathrm{H} \\
\mathrm{Fe}^{2+}\left(\mathrm{T}_{\mathrm{d} 3}\right), \mathrm{H} \\
\mathrm{Fe}^{3+}\left(\mathrm{T}_{\mathrm{d} 4}\right), \mathrm{H}\end{array}$ \\
\hline HeMn5 & $\begin{array}{l}\mathrm{QD}_{1} \\
\mathrm{QD}_{2} \\
\mathrm{QD}_{3} \\
\mathrm{QD}_{4}\end{array}$ & $\begin{array}{l}1.023(11) \\
0.970(6) \\
0.938(12) \\
0.306(4)\end{array}$ & $\begin{array}{l}2.141(25) \\
1.717(34) \\
1.152(63) \\
0.994(8)\end{array}$ & $\begin{array}{l}0.147(23) \\
0.210(40) \\
0.241(31) \\
0.203(6)\end{array}$ & $\begin{array}{l}12.6(4) \\
27.9(8) \\
20.1(6) \\
39.4(4)\end{array}$ & $1.54 \pm 0.03$ & $\begin{array}{l}\mathrm{Fe}^{2+}\left(\mathrm{T}_{\mathrm{d} 1}\right), \mathrm{H} \\
\mathrm{Fe}^{2+}\left(\mathrm{T}_{\mathrm{d} 2}\right), \mathrm{H} \\
\mathrm{Fe}^{2+}\left(\mathrm{T}_{\mathrm{d} 3}\right), \mathrm{H} \\
\mathrm{Fe}^{3+}\left(\mathrm{O}_{\mathrm{h}}\right), \mathrm{H}\end{array}$ \\
\hline HeMn7 & $\begin{array}{l}\mathrm{QD}_{1} \\
\mathrm{QD}_{2} \\
\mathrm{QD}_{3} \\
\mathrm{QD}_{4}\end{array}$ & $\begin{array}{l}0.997(13) \\
0.990(1) \\
0.932(22) \\
0.332(6)\end{array}$ & $\begin{array}{l}2.073(62) \\
1.533(52) \\
0.970(46) \\
1.019(11)\end{array}$ & $\begin{array}{l}0.174(45) \\
0.203(8) \\
0.186(52) \\
0.215(47)\end{array}$ & $\begin{array}{r}15.8(4) \\
30.0(1) \\
5.2(3) \\
49.0(2)\end{array}$ & $1.04 \pm 0.01$ & $\begin{array}{l}\mathrm{Fe}^{2+}\left(\mathrm{T}_{\mathrm{d} 1}\right), \mathrm{H} \\
\mathrm{Fe}^{2+}\left(\mathrm{T}_{\mathrm{d} 2}\right), \mathrm{H} \\
\mathrm{Fe}^{2+}\left(\mathrm{T}_{\mathrm{d} 3}\right), \mathrm{H} \\
\mathrm{Fe}^{3+}\left(\mathrm{O}_{\mathrm{h}}\right), \mathrm{H}\end{array}$ \\
\hline
\end{tabular}

${ }^{1}$ hercynite. Abbreviations: IS - isomer shift, QS - nuclear quadrupole splitting, $\Gamma$ - full width at half maximum. 
Table 2. The hyperfine parameters for spinel series $\left(\mathrm{Fe}_{1-x} \mathrm{Mn}_{x}\right) \mathrm{Al}_{2} \mathrm{O}_{4}$, where $x=0.3,0.5,0.7$

\begin{tabular}{|c|c|c|c|c|c|c|c|}
\hline Sample & Component & $\begin{array}{c}\mathrm{IS} \\
{[\mathrm{mm} / \mathrm{s}]}\end{array}$ & $\begin{array}{c}\mathrm{QS} \\
{[\mathrm{mm} / \mathrm{s}]}\end{array}$ & $\begin{array}{c}\Gamma \\
{[\mathrm{mm} / \mathrm{s}]}\end{array}$ & $\begin{array}{c}\text { Area } \\
{[\%]}\end{array}$ & $\mathrm{Fe}^{2+} / \mathrm{Fe}^{3+}$ & $\begin{array}{c}\text { Position } \\
\text { assignment }\end{array}$ \\
\hline $\mathrm{He} 0$ & $\begin{array}{l}\mathrm{QD}_{1} \\
\mathrm{QD}_{2} \\
\mathrm{QD}_{3} \\
\mathrm{QD}_{4}\end{array}$ & $\begin{array}{l}0.945(2) \\
0.941(2) \\
0.920(2) \\
0.345(4)\end{array}$ & $\begin{array}{l}2.241(9) \\
1.680(9) \\
1.032(2) \\
0.758(7)\end{array}$ & $\begin{array}{l}0.183(7) \\
0.235(2) \\
0.311(7) \\
0.190(5)\end{array}$ & $\begin{array}{l}17.9(2) \\
32.0(4) \\
39.3(3) \\
10.8(2)\end{array}$ & $8.265 \pm 0.08$ & $\begin{array}{l}\mathrm{Fe}^{2+}\left(\mathrm{T}_{\mathrm{d} 1}\right), \mathrm{H}^{1} \\
\mathrm{Fe}^{2+}\left(\mathrm{T}_{\mathrm{d} 2}\right), \mathrm{H} \\
\mathrm{Fe}^{2+}\left(\mathrm{T}_{\mathrm{d} 3}\right), \mathrm{H} \\
\mathrm{Fe}^{3+}\left(\mathrm{O}_{\mathrm{h}}\right), \mathrm{H}\end{array}$ \\
\hline HeMn3 & $\begin{array}{l}\mathrm{QD}_{1} \\
\mathrm{QD}_{2} \\
\mathrm{QD}_{3} \\
\mathrm{QD}_{4}\end{array}$ & $\begin{array}{l}1.010(7) \\
0.960(4) \\
0.934(7) \\
0.284(4)\end{array}$ & $\begin{array}{l}2.112(17) \\
1.662(25) \\
1.088(46) \\
0.968(7)\end{array}$ & $\begin{array}{l}0.169(14) \\
0.205(31) \\
0.242(22) \\
0.200(3)\end{array}$ & $\begin{array}{l}21.7(3) \\
26.7(7) \\
19.4(3) \\
32.2(8)\end{array}$ & $2.11 \pm 0.03$ & $\begin{array}{l}\mathrm{Fe}^{2+}\left(\mathrm{T}_{\mathrm{d} 1}\right), \mathrm{H} \\
\mathrm{Fe}^{2+}\left(\mathrm{T}_{\mathrm{d} 2}\right), \mathrm{H} \\
\mathrm{Fe}^{2+}\left(\mathrm{T}_{\mathrm{d} 3}\right), \mathrm{H} \\
\mathrm{Fe}^{3+}\left(\mathrm{T}_{\mathrm{d} 4}\right), \mathrm{H}\end{array}$ \\
\hline HeMn5 & $\begin{array}{l}\mathrm{QD}_{1} \\
\mathrm{QD}_{2} \\
\mathrm{QD}_{3} \\
\mathrm{QD}_{4}\end{array}$ & $\begin{array}{l}1.023(11) \\
0.970(6) \\
0.938(12) \\
0.306(4)\end{array}$ & $\begin{array}{l}2.141(25) \\
1.717(34) \\
1.152(63) \\
0.994(8)\end{array}$ & $\begin{array}{l}0.147(23) \\
0.210(40) \\
0.241(31) \\
0.203(6)\end{array}$ & $\begin{array}{l}12.6(4) \\
27.9(8) \\
20.1(6) \\
39.4(4)\end{array}$ & $1.54 \pm 0.03$ & $\begin{array}{l}\mathrm{Fe}^{2+}\left(\mathrm{T}_{\mathrm{d} 1}\right), \mathrm{H} \\
\mathrm{Fe}^{2+}\left(\mathrm{T}_{\mathrm{d} 2}\right), \mathrm{H} \\
\mathrm{Fe}^{2+}\left(\mathrm{T}_{\mathrm{d} 3}\right), \mathrm{H} \\
\mathrm{Fe}^{3+}\left(\mathrm{O}_{\mathrm{h}}\right), \mathrm{H}\end{array}$ \\
\hline HeMn7 & $\begin{array}{l}\mathrm{QD}_{1} \\
\mathrm{QD}_{2} \\
\mathrm{QD}_{3} \\
\mathrm{QD}_{4}\end{array}$ & $\begin{array}{l}0.997(13) \\
0.990(1) \\
0.932(22) \\
0.332(6) \\
\end{array}$ & $\begin{array}{l}2.073(62) \\
1.533(52) \\
0.970(46) \\
1.019(11) \\
\end{array}$ & $\begin{array}{l}0.174(45) \\
0.203(8) \\
0.186(52) \\
0.215(47) \\
\end{array}$ & $\begin{array}{r}15.8(4) \\
30.0(1) \\
5.2(3) \\
49.0(2) \\
\end{array}$ & $1.04 \pm 0.01$ & $\begin{array}{l}\mathrm{Fe}^{2+}\left(\mathrm{T}_{\mathrm{d} 1}\right), \mathrm{H} \\
\mathrm{Fe}^{2+}\left(\mathrm{T}_{\mathrm{d} 2}\right), \mathrm{H} \\
\mathrm{Fe}^{2+}\left(\mathrm{T}_{\mathrm{d} 3}\right), \mathrm{H} \\
\mathrm{Fe}^{3+}\left(\mathrm{O}_{\mathrm{h}}\right), \mathrm{H}\end{array}$ \\
\hline
\end{tabular}

${ }^{1}$ hercynite. Abbreviations: IS - isomer shift, QS - nuclear quadrupole splitting, $\Gamma$ - full width at half maximum.

obtained in this study were distributed among the tetrahedral sites that exhibited three different symmetries, which is confirmed by the different values of QS with the $\mathrm{QD}_{1}$ component of the highest tetrahedron deformation.

It can be observed from Fig. 2 that the experimental spectrum for pure hercynite clearly differs from the ones for the Mn-substituted hercynite. This is a result of the greater contribution of the $\mathrm{QD}_{4}$ component, which is related to the ferric ions present in the crystal lattice of $\left(\mathrm{Fe}_{1-x} \mathrm{Mn}_{x}\right) \mathrm{Al}_{2} \mathrm{O}_{4}$ samples with $x>0$. $\mathrm{Fe}^{3+}$ ions were previously reported in hercynite spinels [27, 28] with an average IS = $0.47 \mathrm{~mm} / \mathrm{s}$ [28] and $0.30(2) \mathrm{mm} / \mathrm{s}$ [27]. Moreover, it was reported that a limited amount of $\mathrm{Fe}^{3+}$ may dissolve in the hercynite spinel structure [29]. According to the decomposition of experimental spectra using Lorentzian line shapes, the amount of $\mathrm{Fe}^{3+}$ in hercynite that was obtained in this study, was only about $11 \%$. This value describes the degree of spinel inversion. However, the relative area for $\mathrm{QD}_{4}$ increased as Mn content increased and reached a maximum of 49\% for the HeMn7 sample. This increase in the content of ferric ions in spinels referred to a decrease in the $\mathrm{Fe}^{2+}$ to $\mathrm{Fe}^{3+}$ ratio from 8.75 to 1.04 (Table 2) for $\mathrm{He} 0$ and $\mathrm{HeMn} 7$, respectively.

Interestingly, the $\mathrm{Fe}^{3+}$ ions were assigned to octahedral sites $\left(\mathrm{O}_{\mathrm{h}}\right)$ in all of the investigated samples except for HeMn3 in which they were ascribed to $\mathrm{T}_{\mathrm{d}}$ positions due to a significantly lower value of IS $=0.284(4) \mathrm{mm} / \mathrm{s}$. This phenomenon explains the lower oxygen positional parameter $u=0.254(1)$ that was obtained for this sample in which smaller ferric ions $\left(r_{\mathrm{Fe} 3+}=0.049 \mathrm{~nm},[6]\right)$ are located in the

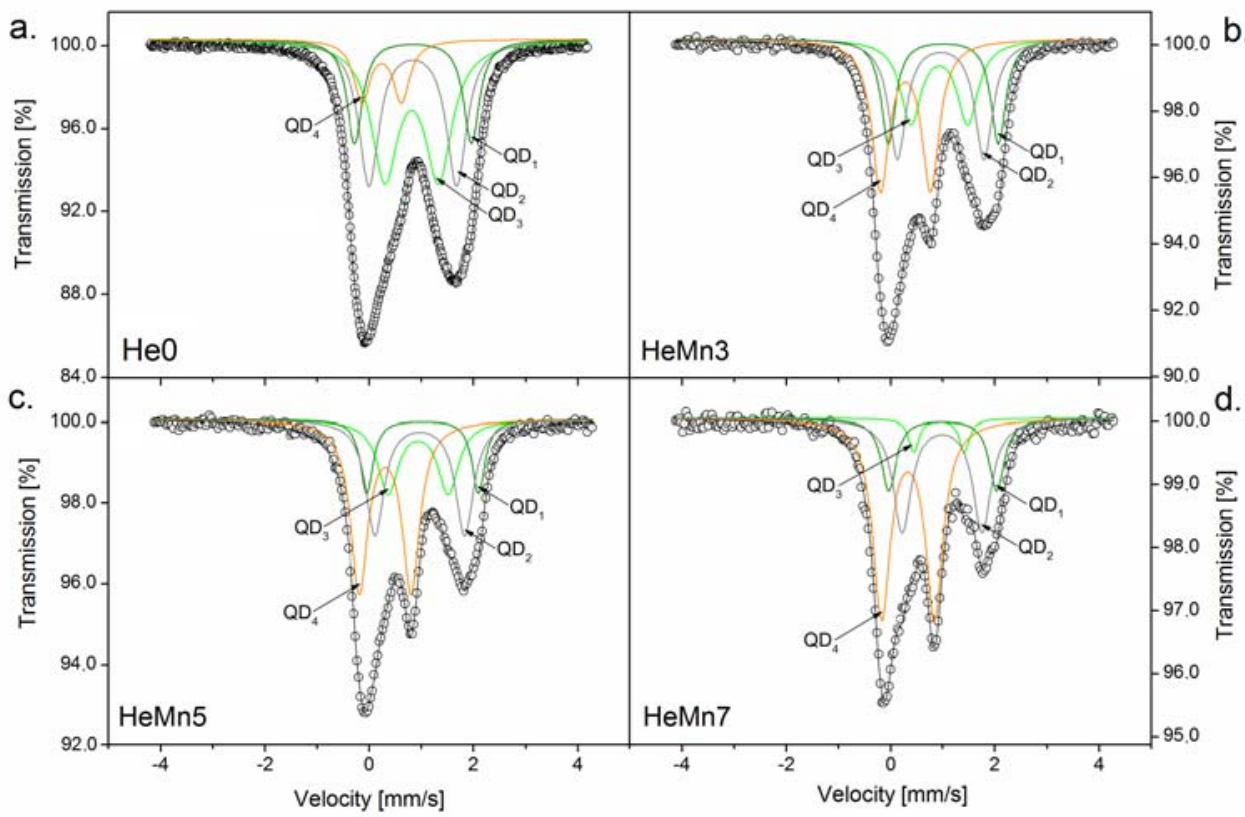

Fig. 2. The ${ }^{57} \mathrm{Fe}$ Mössbauer spectra of the investigated spinel series at room temperature. 
Table 3. Chemical formulas of the obtained materials together with their spinel inversion parameters

\begin{tabular}{|c|c|c|}
\hline Sample & $\begin{array}{l}\text { Chemical formula of the obtained } \\
\text { compound }\end{array}$ & $\begin{array}{c}\text { Inversion parameter, } i \\
{[\%]}\end{array}$ \\
\hline $\begin{array}{l}\text { He0 } \\
\text { HeMn3 } \\
\text { HeMn5 } \\
\text { HeMn7 } \\
\end{array}$ & $\begin{array}{c}\left(\mathrm{Fe}^{2+}{ }_{0.89} \mathrm{Al}_{0.11}\right)\left[\mathrm{Fe}^{3+}{ }_{0.11} \mathrm{Al}_{1.85} \square_{0.04}\right] \mathrm{O}_{4} \\
\left(\mathrm{Fe}^{2+}{ }_{0.47} \mathrm{Mn}_{0.3} \mathrm{Fe}^{3+}{ }_{0.23}\right)\left[\mathrm{Al}_{1.77} \square_{0.23}\right] \mathrm{O}_{4} \\
\left(\mathrm{Fe}^{2+}{ }_{0.3} \mathrm{Mn}_{0.5} \mathrm{Al}_{0.2}\right)\left[\mathrm{Fe}^{3+}{ }_{0.39} \mathrm{Al}_{1.54} \square_{0.07}\right] \mathrm{O}_{4} \\
\left(\mathrm{Fe}^{2+}{ }_{0.15} \mathrm{Mn}_{0.7} \mathrm{Al}_{0.15}\right)\left[\mathrm{Fe}^{3+}{ }_{0.49} \mathrm{Al}_{1.46} \square_{0.05} \mathrm{O}_{4}\right.\end{array}$ & $\begin{array}{l}11 \pm 1 \\
23 \pm 1 \\
20 \pm 1 \\
15 \pm 1 \\
\end{array}$ \\
\hline
\end{tabular}

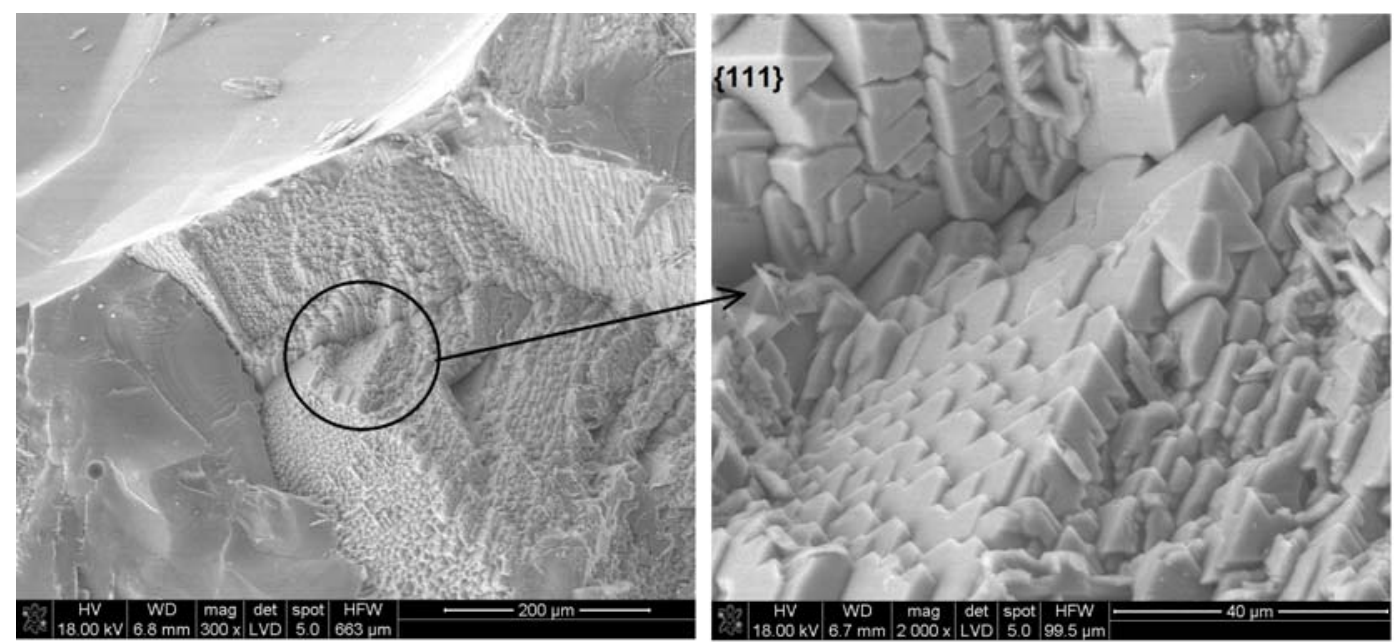

Fig. 3. SEM images of the HeMn3 sample and a fracture image at $300 \times$ (left image) and $2000 \times$ (right image) magnifications.

tetrahedral sites, thus shrinking them. This suggests that for the substitutions of lower manganese contents, $\mathrm{Mn}$ atoms prefer to occupy the $\mathrm{O}_{\mathrm{h}}$ positions in the spinel structure.

Table 3 presents the actual chemical formulas of the investigated compositions that were synthesized using arc plasma synthesis. These formulas were established based on the results obtained from the analysis of Mössbauer effect measurements. It should be mentioned that the manganese ions were assumed to be fixed in $\mathrm{T}_{\mathrm{d}}$ sites, as was shown by the theoretical (Table 1) and actual (Table 3) chemical formulas of the obtained spinel series. This result is also supported by the previous studies [18].

Due to the excess of the charge at $\mathrm{T}_{\mathrm{d}}$ sites, vacancies had to be introduced. It was previously reported [30-32] that the vacancies in the spinel structure prefer to occupy $\mathrm{O}_{\mathrm{h}}$ sites. A decrease in the number of vacancies as manganese content increased could be observed. This was followed by a drop in the value of the spinel inversion parameter from $i=23 \%$ to $i=15 \%$ for HeMn3 and HeMn7, respectively.

\section{Scanning electron microscopy observations}

Figure 3 presents an SEM image of the microstructure of the arc plasma-melted Mn-substituted hercynite for the HeMn3 composition. The sample had a form of a fracture surface. It can be observed from this microphotograph that the material is dense and compact. The fracture surface revealed numerous crystals, most of which were about $20 \mu \mathrm{m}$ in diameter. A few of them exhibited a completely octahedral habit while the rest were not well-developed. The octahedral habit of the crystals with a spinel struc- ture is preferred since almost flat crystallographically equivalent surfaces $\{111\}$ exhibit a privileged growth direction. These planes are energetically favourable habit planes (sets of planes on which crystals tend to grow) in the case of spinels, according to the Bravais-Friedel-Donnay-Harker (BFDH) rule since they posses the largest interplanar distances $d_{111}$. Therefore, they constitute one of the most important factors that influence the evolution of spinel morphology $[33,34]$.

\section{Conclusions}

In this work, a series of Mn-substituted hercynite spinels were synthesized using arc plasma. The microstructural characterization of the obtained materials showed that the single phase materials of spinel structures with compositions from pure hercynite to Mn-substituted hercynite and molar fractions of $x=0.3,0.5$ and 0.7 of Mn can be obtained using arc plasma.

By increasing the amount of $\mathrm{Mn}^{2+}$ ions in hercynite, the $\mathrm{Fe}^{2+}$ to $\mathrm{Fe}^{3+}$ ratios decreased, along with reductions in the inversion parameters and decreases in the amounts of the octahedrally coordinated vacancies.

In addition, the microstructure of the obtained spinel materials was compact with sparsely occurring voids and crystals of the octahedral habits.

Acknowledgments. The work was supported by the statutory funds of the Faculty of Materials Science and Ceramics at the AGH University of Science and Technology in Cracow. 


\section{References}

1. Sickafus, K. E., Wills, J. M., \& Grimes, N. W. (1999). Structure of spinel. J. Am. Ceram. Soc., 82(12), 3279-3292. DOI: 10.1111/j.1151-2916.1999. tb02241.x.

2. Amirkhanyan, L., Weissbach, T., Kortus, J., \& Aneziris, Ch. G. (2013). On the possibility of hercynite formation in a solid state reaction at the $\mathrm{Al}_{2} \mathrm{O}_{3}$-iron interface: A density-functional theory study. Ceramics Int., 40 (1, Pt. A), 257-262.

3. Verwey, E. J. W., \& Heilmann, E. L. (1947). Physical properties and cation arrangement of oxides with spinel structures. I. Cation arrangements in spinels. J. Chem. Phys., 15, 174-180. DOI: 10.1063/1.1746464.

4. Blaney, L. (2007). Magnetite $\left(\mathrm{Fe}_{3} \mathrm{O}_{4}\right)$ : Properties, synthesis, and applications. Leigh Review, 15, 33-81. http://preserve.lehigh.edu/cas-lehighreview-vol-15/5.

5. Essene, E. J., \& Peacor, D. R. (1983). Crystal chemistry and petrology of coexisting galaxite and jacobsite and other spinel solutions and solvi. Am. Miner., 68, 449-455.

6. Shannon, R. D. (1976). Revised effective ionic radii and systematic studies of interatomic distances in halides and chalcogenides. Acta Crystallogr. Sect. A, 32, 751-767.

7. Jastrzębska, I., Szczerba, J., \& Stoch, P. (2017). Structural and microstructural study on the arc-plasma synthesized (APS) $\mathrm{FeAl}_{2} \mathrm{O}_{4}-\mathrm{MgAl}_{2} \mathrm{O}_{4}$ transitional refractory compound. High Temp. Mater. Process., 36(3), 299-304. DOI: 10.1515/htmp-2015-0252.

8. Turnock, A. C., \& Eugster, H. P. (1962). Fe-Al oxides: phase relations below $1000^{\circ} \mathrm{C}$. J. Petrol., 3, 533-565.

9. Turnock, A. C., \& Lindsley, D. H. (1961). Fe-Al and Fe-Ti spinels and related oxides. In Year Book Carnegie Institution of Washington (vol. 60, pp. 152-157). Washington, D.C.: Carnegie Institution of Washington.

10. Cremer, V. (1969). Die Mischkristallbildung im System Chromit-Magnetit-Hercynit zwischen $1000^{\circ}$ und $500^{\circ} \mathrm{C}$. Neues Jahrb. Mineral. Abh., 111(2), 184-205.

11. Hålenius, U., Bosi, F., \& Skokby, H. (2007). Galaxite, $\mathrm{MnAl}_{2} \mathrm{O}_{4}$, a spectroscopic standard for tetrahedrally coordinated $\mathrm{Mn}^{2+}$ in oxygen-based mineral structures. Am. Miner., 92, 1225-1231.

12. Fischer, W. A., \& Hoffmann, A. (1956). Das Zustandsschaubild Eisenoxydul-Aluminiumoxyd. Arch. Eisenhuettenwes. 27(5), 343-346.

13. Jacob, K. T. (1981). Revision of thermodynamic data on $\mathrm{MnO}-\mathrm{Al}_{2} \mathrm{O}_{3}$ melts. Can. Metall. Q., 20(1), 89-92. DOI: http://dx.doi.org/10.1179/cmq.1981.20.1.89.

14. Jastrzębska, I., Szczerba, J., Błachowski, A., \& Stoch, P. (2017). Structure and microstructure evolution of hercynite spinel $\left(\mathrm{Fe}^{2+} \mathrm{Al}_{2} \mathrm{O}_{4}\right)$ after annealing treatment. Eur. J. Mineral., 29(1), 63-72. DOI: 10.1127/ ejm/2017/0029-2579.

15. Liu, G., Li, N., Yan, W., Tao, G., \& Li, Y. (2012). Composition and structure of a composite spinel made from magnesia and hercynite. J. Ceram. Proc. Res., 13(4), 480-485.

16. Gelbmann, G., Krischanitz, R., \& Jörg, S. (2013). Hybrid spinel technology provides performance advances for basic cement rotary kiln bricks. RHI Bull., 2, 10-12.

17. Woodland, A. B., \& Wood, B. J. (1990). The breakdown of hercynite at low $\mathrm{f}_{\mathrm{O} 2}$. Am. Miner., 75, 1342-1348.

18. Bromiley, G. D., Gatta, G. D., \& Stokes, T. (2015). Manganese incorporation in synthetic hercynite. Miner. Mag., 79(3), 635-647. DOI: 10.1180/minmag.2015.079.3.09.
19. Jastrzębska, I., \& Szczerba, J. (2015). Non-conventional method of ceramic preparation - arc plasma synthesis (APS). In: X Krakow Conference of Young Scientists, KKMU Symposia and Conferences 10, 24-26 September 2015 (pp. 9-10). Krakow: AGH University of Science and Technology.

20. Jastrzębska, I., Szczerba, J., Stoch, P., Błachowski, A., Ruebenbauer, K., Prorok, R., \& Śnieżek, E. (2015). Crystal structure and Mössbauer study of $\mathrm{FeAl}_{2} \mathrm{O}_{4}$. Nukleonika, 60(1), 47-49. DOI: 10.1515/ nuka-2015-0012.

21. Degen, T., Sadki, M., Bron, E., König, U., \& Nénert, G. (2014). The HighScore suite. Powder Diffr., 29, S13-S18. DOI: http://dx.doi.org/10.1017/ S0885715614000840.

22. Lutterotti, L., Matthies, S., \& Wenk, H. R. (1999). MAUD (Material Analysis Using Diffraction): A user friendly Java program for Rietveld texture analysis and more. In: Proceedings of the Twelfth International Conference on Textures of Materials (ICOTOM-12), 9-13 August 1999, McGill University, Montreal, Canada (vol. 1, p. 1599). Ottawa: National Research Press.

23. Prisecaru, I. (2009-2016). WMOSS4 Mössbauer Spectral Analysis Software. Available from http:// www.wmoss.org.

24. Hill, R. J. (1984). X-ray powder diffraction profile refinement of synthetic hercynite. Am. Miner., 69, 937-942.

25. Lucchesi, S., Russo, U., \& Della Giusta, A. (1997). Crystal chemistry and cation distribution in some Mn-rich natural and synthetic spinels. Eur. J. Mineral., 9, 31-42. DOI: 10.1127/ejm/9/1/0031.

26. O'Neill, H., Hugh, St. C., \& Navrotsky, A. (1983). Simple spinels: crystallographic parameters, cation radii, lattice energies and cation distribution. Am. Miner., 68, 181-194.

27. Dézsi, I., Szűcs, I., \& Sváb, E. (2000). Mössbauer spectroscopy of spinels, J. Radiat. Nucl. Chem., 246(1), 15-19. DOI: 10.1023/A:1006796022996.

28. Larsson, L., O'Neill, H., \& Annersten, H. (1994). Crystal chemistry of synthetic hercynite $\left(\mathrm{FeAl}_{2} \mathrm{O}_{4}\right)$ from XRD structural refinements and Mössbauer spectroscopy. Eur. J. Mineral., 6, 39-51. DOI: 10.1127/ejm/6/1/0039.

29. Muan, A., \& Gee, C. L. (1956). Phase equilibrium studies in the system iron oxide $\mathrm{Al}_{2} \mathrm{O}_{3}$ in air and at 1 atm $\mathrm{O}_{2}$ pressure. J. Am. Ceram. Soc., 39(6), 207-214. DOI: 10.1111/j.1151-2916.1959.tb13581.x.

30. Menegazzo, G., Carbonin, S., \& Della Giusta, A. (1997). Cation and vacancy distribution in an artificially oxidized natural spinel. Mineral. Mag., 61, 411-421. DOI: 10.1180/minmag.1997.061.406.07.

31. Jagodzinski, H., \& Saalfeld, H. (1958). Cation distribution and structural relations in Mg-Al spinels. Z. Kristallogr., 110(3), 197-218. DOI: 10.1524/ zkri.1958.110.16.197. (in German).

32. Sheldon, R. I., Hartmann, T., Sickafus, K. E., Ibarra, A., Scott, B. L., Argyriou, D. N., Larson, A. C., \& Von Dreel, R. B. (1999). Cation disorder and vacancy distribution in nonstoichiometric magnesium aluminate spinel, $\mathrm{MgO} \cdot \mathrm{xAl}_{2} \mathrm{O}_{3}$. J. Am. Ceram. Soc., 82(12), 3293-3298. DOI: 10.1111/j.1151-2916.1999. tb02242.x.

33. Brice, J. C. (1986). Crystal growth processes. New York: Wiley. DOI: 10.1002/crat.2170220103.

34. Roy, B. N. (1992). Crystal growth from melts. Applications to growth of groups 1 and 2 crystals. New York: Wiley. DOI: 10.1002/crat.2170270615. 